\title{
Rheological properties of white blood cells are changed in diabetic patients with microvascular complications
}

\author{
I. Vermes ${ }^{1}$, E.T.Steinmetz ${ }^{2}$, L. J.J. M.Zeyen ${ }^{1}$ and E.A. van der Veen ${ }^{3}$ \\ Departments of ${ }^{1}$ Clinical Chemistry and ${ }^{2}$ Ophthalmology, H.d.K. Hospital, Oldenzaal, and \\ ${ }^{3}$ Department of Endocrinology, Free University Hospital, Amsterdam, The Netherlands
}

Summary. Erythrocyte and white blood cell suspensions were prepared from 22 Type 1 (insulin-dependent) and 37 Type 2 (non-insulin-dependent) diabetic patients and from 57 control subjects. Cell filterability was studied with the new "St.George's Filtrometer", which can discriminate between cell deformability and filter occlusion. A pronounced increase of filter clogging was found in diabetic patients compared with control subjects. There was no significant difference between Type 1 and Type 2 diabetic patients, but a significantly increased clogging was found in patients with retinopathy compared with retinopathy-free patients. Considering that filter occlusion is mainly due to leucocytes, our results show a reduced filterability of white blood cells in diabetic patients. Altered white blood cell function may act as an additional factor in the impairment of microvascular circulation in diabetic patients.

Key words: Diabetes, retinopathy, haemorheology, filterability, erythrocyte, leucocyte.
The pathogenesis of diabetic microangiopathy is unclear, but there is general agreement that, in addition to vascular components, haemorheological disturbances can play a role in the impairment of microvascular flow [1]. Disturbed rheology of blood caused by increased plasma and whole blood viscosity, increased aggregation and rigidity of erythrocytes may act as additional factors in diabetic microangiopathy [2]. Unfortunately published results are rather controversial $[2,3]$. Due to methodological difficulties less attention has been focused on rheological properties of leucocytes of diabetic patients. Recently a new blood filtration technique was introduced which enables investigation of rheological behavior of white blood cells [4]. By using this technique very recently Ernst and Matrai [5] demonstrated a reduced white cell filterability and a slight overall loss of erythrocyte fluidity in blood suspensions with standardised erythrocyte and leucocyte counts of Type 2 diabetic patients. We investigated the filterability of isolated erythrocytes and white blood cells of diabetic patients with and without microvascular complications.

\section{Subjects and methods}

Clinical data and blood samples were collected from 59 diabetic patients and 57 control subjects. Exclusion criteria were fasting blood glucose over $15 \mathrm{mmol} / \mathrm{l}$, blood serum osmolality over $295 \mathrm{mosmol} /$ $\mathrm{kg}$, pathological haemathological indices or abnormalities of differential leucocyte counts. Twenty-two patients were diagnosed as Type 1 and 37 as Type 2. The Type 1 diabetic patients included 10 women and 12 men with a mean age of 29 years (range 9-62 years), with a mean duration of diabetes of 12 years. In the Type 2 group 17 patients were controlled with insulin and 20 with diet and oral hypoglycaemic drugs. The insulin-treated Type 2 subgroup included 10 women and 7 men with a mean age of 60 years (range 36-77 years) and a mean duration of diabetes of 12 years. In the subgroup treated with oral hypoglycaemic drugs were 12 women and 8 men with a mean age of 55 years (39-77 years), with a mean duration of diabetes of 14 years. All patients had undergone full ophthalmological examination including fundus photography and fluorescein angiography and were classified as non-retinopathic (35 patients), background retinopathy (16 patients) and proliferative retinopathy ( 8 patients). The control group included 57 non-diabetic subjects ( 32 female, 25 male, mean age 52 years and an age range of 16-67 years).

Venous blood was collected between $8.00-10.00$ hours after an overnight fast with minimal occlusion and EDTA was used as anticoagulant. Erythrocyte and white blood cell suspensions were prepared according to previously published methods [6]. The white cell contamination in the erythrocyte suspension was $<0.1 \times 10^{9} / 1$ and platelet contamination was not detectable. An erythrocyte concentration of $10 \%$ was used for the filtration. The erythrocyte contamination of the white cell suspension was not detectable and $1 \times 10^{9} \mathrm{cell} / 1$ was used for the filtration measurements. The differential leucocyte count was controlled after the isolation and only cell suspensions with a lymphocyte percentage between $30-40 \%$ were included.

Filtrations of cell suspensions were carried out with a "St. George's Filtrometer" (Carri-Med Ltd., Dorking, UK) at $25^{\circ} \mathrm{C}$, using polycarbonate membrane filters (Nucleopore, Pleasanton, $\mathrm{Ca}$ lif, USA) batch no. $5404 \mathrm{C} 48$ nominal pore diameter $5 \mu \mathrm{m}$, filter diameter $13 \mathrm{~mm}$, effective filtration area $0.78 \mathrm{~cm}^{2}$, with a driving pres- 
Table 1. Filtration results of erythrocyte and white blood cell suspensions of Type 1 (insulin-dependent) and Type 2 (non-insulin-dependent) diabetic patients and control subjects

\begin{tabular}{|c|c|c|c|c|c|c|}
\hline & $\begin{array}{l}\text { Control } \\
\text { subjects } \\
(n=57)\end{array}$ & $\begin{array}{l}\text { Diabetic } \\
\text { patients } \\
(n=59)\end{array}$ & $\begin{array}{l}\text { Type } 1 \\
\text { diabetes mellitus } \\
(n=22)\end{array}$ & $\begin{array}{l}\text { Type } 2 \\
\text { diabetes mellitus } \\
(n=37)\end{array}$ & $\begin{array}{l}\text { No retino- } \\
\text { pathy } \\
(n=35)\end{array}$ & $\begin{array}{l}\text { Retinopathy } \\
(n=24)\end{array}$ \\
\hline Initial filtration rate & $\begin{array}{r}0.539 \\
\pm 0.004\end{array}$ & $\begin{array}{r}0.534 \\
\pm 0.009\end{array}$ & $\begin{array}{r}0.533 \\
\pm 0.011\end{array}$ & $\begin{array}{r}0.535 \\
\pm 0.013\end{array}$ & $\begin{array}{r}0.535 \\
\pm 0.010\end{array}$ & $\begin{array}{r}0.533 \\
\pm 0.012\end{array}$ \\
\hline Erythrocyte transit time & $\begin{aligned} & 10.38 \\
\pm & 0.18\end{aligned}$ & $\begin{array}{l}10.34 \\
\pm 0.21\end{array}$ & $\begin{array}{l}10.50 \\
\pm 0.23\end{array}$ & $\begin{array}{l}10.18 \\
\pm 0.28\end{array}$ & $\begin{array}{l}10.36 \\
\pm 0.22\end{array}$ & $\begin{array}{l}10.32 \\
\pm 0.24\end{array}$ \\
\hline \multicolumn{7}{|c|}{ White cell suspension $\left(1 \times 10^{9}\right.$ cell $\left./ 1\right)$} \\
\hline Initial filtration rate & $\begin{array}{r}0.936 \\
\pm 0.012\end{array}$ & $\begin{array}{r}0.932 \\
\pm 0.012\end{array}$ & $\begin{array}{r}0.956 \\
\pm 0.009\end{array}$ & $\begin{array}{r}0.908 \\
\pm 0.014\end{array}$ & $\begin{array}{r}0.946 \\
\pm 0.016\end{array}$ & $\begin{array}{r}0.918 \\
\pm 0.012\end{array}$ \\
\hline Clogging particles $\left(\mathrm{ml}^{-1}\right)$ & $\begin{aligned} & 98798 \\
+ & 3300\end{aligned}$ & $\begin{aligned} & 146668^{\mathrm{b}} \\
\pm & 5588\end{aligned}$ & $\begin{aligned} & 166800^{\mathrm{a}} \\
\pm & 9685\end{aligned}$ & $\begin{aligned} & 126858^{\mathrm{c}} \\
\pm & 5685\end{aligned}$ & $\begin{aligned} & 126000^{\circ} \\
\pm & 6508\end{aligned}$ & $\begin{aligned} & 167658^{a} \\
\pm & 13285\end{aligned}$ \\
\hline
\end{tabular}

Results are expressed as mean $\pm \mathrm{SD} .{ }^{\mathrm{a}} p<0.001 ;{ }^{\mathrm{b}} p<0.01 ;{ }^{\mathrm{c}} p<0.05$ compared with control subjects

sure of $-4 \mathrm{~cm}$ water. Phosphate buffered saline $(0.01 \mathrm{~mol} / 1, \mathrm{pH} 7.4$, osmolality $295 \mathrm{mosmol} / \mathrm{kg}$ ) was prefiltered through a filter with a pore of $1 \mu \mathrm{m}$ diameter to eliminate contaminating particles. The filter to filter variation was $<5 \%$. All samples were measured in duplicate.

\section{Statistical analysis}

Results are presented as mean $\pm S D$, and statistical evaluation was performed by using analysis of variance.

\section{Results}

There were no significant differences between the control subjects and diabetic patients with respect to the initial filtration rate and erythrocyte transit time when filtering erythrocyte suspensions (Table 1). However, the number of clogging particles during erythrocyte filtration was significantly higher in diabetic patients compared with control subjects $(p<0.01)$. There were no significant differences between Type 1 and Type 2 diabetic patients. A significantly increased clogging was found in patients with retinopathy compared to retinopathy-free diabetic patients $(p<0.05)$. These differences were more pronounced when filtering white cell suspensions (Table 1). A significantly higher number of clogging particles of white cell suspensions was found in diabetic patients than in control subjects $(p<0.01)$. In addition, significantly increased clogging was observed in patients with retinopathy compared with the retinopathy-free group $(p<0.01)$.

\section{Discussion}

An impaired erythrocyte deformability in diabetes mellitus has been shown by many authors $[2,3]$ and it is largely based on the results of filterability studies.
However, more recent results showed that blood filtration reflects not only erythrocyte flexibility but also retention of blood components other than erythrocyte e. g. white cells in the filter [7]. Early filtration methods could not differentiate between these two major components influencing filtration. Therefore the contribution of leucocytes to the altered blood filterability of diabetic patients till now was speculative. The recently described "St. George's Filtrometer" is capable of differentiating between these two factors effecting blood filterability by measuring both the initial filtration rate as erythrocyte parameter and the filter clogging as white cell parameter when whole blood is filtered [8]. Employing this sensitive method, an altered erythrocyte and white blood cell rheology was found in Type 2 diabetic patients [5]. Suspensions with standardised erythrocyte and leucocyte counts were filtered, and a significant increase in the filter clogging with a slight increase in initial filtration time was found [5]. By using a different approach we were able to confirm this observation. The data presented show a highly significant increase in filter clogging when erythrocyte with low but detectable white cell contamination, or suspensions with only white cells are filtered. In addition, we demonstrate that increased clogging during blood cell filtration is a more general finding in diabetic patients and not only present in Type 2 diabetic patients. Moreover, we found a positive correlation between the presence of microvascular complications of diabetes and altered white blood cell rheology. Our results do not clarify which leucocyte subpopulations might account for these abnormalities, or what pathophysiological changes are involved in altered leucocyte rheology in these patients. The current reports indicate that white cell rheology is potentially of greatest clinical significance in conditions associated with low microvascular flow [9]. The diabetic retinopathy with arteriolar dilatation and with increased blood pressure in 
the retinal venulas could be an example of such a microcirculation [10]. In view of these observations we surmise that decreased deformability and/or increased adhesiveness of leucocytes can play an additional role in the development of microangiopathy in diabetic patients.

\section{References}

1. Schmid-Schönbein H (1976) Microrheology of erythrocytes, blood viscosity and the distribution of blood flow in microcirculation. In: Guyton AC (ed) Cardiovascular physiology II. University Press, Baltimore, pp 1-62

2. McMillan DE (1983) The effect of diabetes on blood flow properties. Diabetes 32 [Suppl] 2: 56-63

3. Pagano G, Niort G, Pagani A (1986) Some problems of the pharmacologic treatment of haemorheological alterations of diabetes mellitus. Clin Haemorheol 6: 303-323

4. Dormandy J, Flute P, Matrai A, Bogar L, Mikita J, Lowe GDO, Anderson J, Chien S, Schmalzer E, Herschenfeld A (1985) The new St. George's blood filtrometer. Clin Haemorheol 5: 483-491

5. Ernst E, Matrai A (1986) Altered red and white blood cell rheology in type II diabetes. Diabetes 35: 1412-1415
6. Mikita J, Nash G, Dormandy J (1986) A simple method of preparing white blood cells for filterability testing. Clin Haemorheol 6: 635-639

7. Matrai A, Ernst E, Flute PT, Dormandy JA (1984) Blood filterability in peripheral vascular disease - Red cell deformability or cell sticking? Clin Haemorheol 4: 311-325

8. Matrai A, Reid H, Bogar L, Flute PT, Dormandy JA (1985) Initial filtration rate and initial clogging in the Hemorheometer. Biorheology 22: 275-284

9. Chien S, Schmid-Schönbein GW, Sung KLP, Schmalzer EA, Skalak R (1984) Viscoelastic properties of leucocytes. In: Meiselman HJ, Lichtman MA, LaCelle PL (eds) White cell mechanics: basic science and clinical aspects, Alan R.Liss, New York, pp 19-51

10. Wolbarsht ML, Landers MB, Stefansson E (1981) Vasodilatation and the etiology of diabetic retinopathy: a new model. Ophthalmic Surg 12: 104-107

Received: 8 May 1987

Dr. I. Vermes

Department of Clinical Chemistry

H. d. K. Hospital

P.O. Box 5005

NL-7570 GA Oldenzaal

The Netherlands 